\title{
AN ANALYSIS OF TEACHER AND \\ STUDENT TALK IN THE CLASSROOM \\ INTERACTION OF THE EIGHTH GRADE \\ OF SMPNEGERI 18 PURWOREJO
}

\author{
Semi Sukarni and Siti Ulfah \\ English Department Muhammadiyah University of \\ Purworejo
}

\begin{abstract}
The aims of this research are firstly, to describe the interaction used by the teacher and studentsconducted in the classroomof the eighth grade of SMP Negeri 18 Purworejo in the Academic Year 2012/2013; secondly, to know what type of interaction characteristics of the teacher-student talk in the classroom interaction; thirdly, to identify languages used in the classroom interaction used during teaching-learning process.
\end{abstract}

This thesis is a descriptive qualitative study on teacher and student talk in the classroom interaction, particularly on the participants' interaction in SMP N 18 Purworejo. The data of this study are the interaction between the teacher and the students in the classroom. In order to analyze the data, some steps are conducted. The data was taken by recording the classroom interaction. The subject in this research wasthe grade VIIIG of SMP Negeri 18 Purworejo, there were 40 students and one English teacher. The researcher used observation and recording for collecting the data. Flanders' Interaction Analysis was used to identify and analyze teacher-student talk in the classroom interaction.

The result of this study shows that the teacher was more active in the interaction. Meanwhile, the student was less active than 
the teacher. Based on the finding, the researcher concludes that the teacher was dominant in the classroom interaction. The percentage of the teacher talk was $78.15 \%$,whereas the students' participation was $21.16 \%$. The language used by the teacher and the students in classroom interaction wasnot balance between Indonesian and English. Indonesian is $62 \%$ while English is only 38\%. It shows that teacher used more Indonesian than English when she explains the material. The interaction was in three ways communication: interaction between teacher-students, students-teacher, and students-students.

\section{Keywords: student talk, teacher talk, clasroom interaction}

\section{INTRODUCTION}

The objectives of English teaching include the four language skills: listening, speaking, writing, and reading through the mastery of the language components: grammar, vocabulary, and pronunciation. The result of English teaching is influenced by some factors; the teacher, the students, time allocation, methodology, material, teaching material and interaction between the teacher and students in the classroom, and the use of visual aid. The classroom interaction includes all of the classroom events, both verbal interaction and non-verbal interaction. The verbal interaction takes place because of the teacher and students talk, while non-verbal interaction covers gestures or facial expression by the teacher and students when they communicate without using words. These two kinds of talk are important; they dominate the classroom events and influence students' foreign language acquisition. Students learn not only through comprehensible input but also their own output. But a good lesson is not one in which students do all or even most of the talking. Some lesson may be good if they are carefully structured in such away that students do a good deal of talking and at the same time get a lot of feedback from the teacher, both formally and informally. But this is by no means true for all lessons.

One of the guidelines to analyze the interaction activities is by using Flanders' Interaction Analysis Categories (FIAC). FIAC is a 
concept which states that teaching will be effective depending to a large degree on how directly and indirectly teacher influences the students' behaviors. Based on the FIAC, there are three categories in the classroom interaction, they are: teacher talk, students talk, and no/all talk. Teacher talk includes accept feeling, praises, accept/ uses ideas of students, ask question, lecturing, giving direction and criticizing. Student talk includes student talk response and student talk initiation. And no/all talk is the situation which is in silence. (Allwright and Bailey, 1991: 202). In this research the researcher focuses on the following problems:

(1) How is the interaction between a teacher and students conducted in the classroomof the eighth grade of SMP Negeri 18 Purworejo?

(2) What kinds of interaction are found based on the characteristics of the teacher-students' interaction in the classroom?

(3) What languages do the teacher and students use in the classroom interaction during teaching-learning process?

The objectives of the study are:

(1) To describe the interaction between the teacher and students which is conducted in the classroom of SMP Negeri 18 Purworejo..

(2) To identify the kinds of interactions based on the characteristics of the teacher-students' interaction in the classroom are.

(3) To identify the languages used in the classroom interaction during teaching-learning process.

\section{BACKGROUND LITERATURE}

\section{Classroom Interaction}

Classroom interaction is the action performed by the teacher and the students during instruction interrelated. They interact with one another for a number of different reason and on a continued basis throughout the school day.Interaction can be said as the fundamental fact of classroom pedagogy because everything that happens in the classroom happens through a process of live person-toperson interaction (Ellis, 1994:565). 


\section{Teacher Talk}

Hornby has written that talk has some meanings, they are: a conversation or discussion, a talking without action, a lecture or speech, formal discussions or negotiations and a way of speaking (Hornby, 1997: 1220). In the classroom, teachers make adjustments to both language form and language function in order to help communication in the classroom. These adjustments are called 'teacher talk'. (http://www.finchpark.com/courses/glossary.html). From those meanings, it can be known that teacher talk is a major way used by the teacher to convey information, have discussion and negotiations and motivate his students, so he can give the students knowledge and control their behaviour. Teacher talk tends to dominate activities involving explaining and evaluating, which limits students talk in terms of both quantity and meaningful purpose. As a result, children spend more time listening to teacher talk than engaged in active language interaction with either teachers or other students (Carole, 1998: 153).

It has been said before that teacher and students are the factors that establish classroom interaction. Both of them must be in balance. Too much teacher talk will make the students passive and static; they cannot improve their English acquisition from him. But it is wrong to judge or assess teacher talk only by reference to its quantity. It is just as important to assess its quality.. It will be also bad if the teacher has too little talk, the students will not get enough knowledgefrom him. But it is wrong to judge or assess teacher talk only by reference to its quantity. It is just as important to assess its quality.

According to Johnson as quoted by Richard (1992) there are three major aspects of teacher talk, they are:

\section{a. Physiological aspect}

This aspect relates to the voice produced by the teacher. The teacher has to be able to control his voice during he speaks in the classroom.

b. Interpersonal aspect

This aspect related to how the teacher speaks with utterances which is structured appropriately with the situation to the students 
so it can make a good classroom climate.

c. Pedagogical aspect

This aspect related to how teacher organize the lesson, so it can create a good interaction.

From the statement above, it can be known that a teacher has to be able to make his talk balance with student talk, situation and context because it can affect students' language acquisition. It is known that the focus of teacher talk is curriculum, instruction and evaluation-the content of conduct of teaching, so that the teacher's ability to combine and apply the three aspects in his talk is really needed.

\section{Student Talk}

Children havelanguage development when they learn language. It is the same when they learn foreign language in the classroom. Firstly they imitate the teacher talk and they need more time to record everyteacher's talk that it's called 'silent period', then start to express their own idea, having discussion, and finally can get their communicative competence.

Student talk can be said as student's speech when he imitates his teacher's examples, expresses his idea or gives comments and criticism about something in the classroom, because Prabu (1991: 49) said that learners have effort in the language classroom but teacher's role cannot be separated from their effort. A good classroom climate will support the students' effort.

\section{Flanders' Interaction Analysis Categories (FIAC)}

Flanders' Interaction Analysis is a system of classroom interaction analysis. The Flanders' Interaction Analysis Categories (FIAC) consists of ten categories of communication which are said to be inclusive of all communication possibilities. There are seven categories used when the teacher is talking and two categories when the learner is talking. In his pioneering work, Flanders used the term Interaction Analysis for his ten-category observation schedule that 
he had designed for general educational purposes, to be relevant to a variety of lessons rather than for any subject in particular. In his work, he combined a politically powerful idea with a very practical simplicity. The powerful idea was that the teaching was more or less effective depending on how "directly" or "indirectly" teachers influence learner behaviour.

Table 1. The description of FIAC

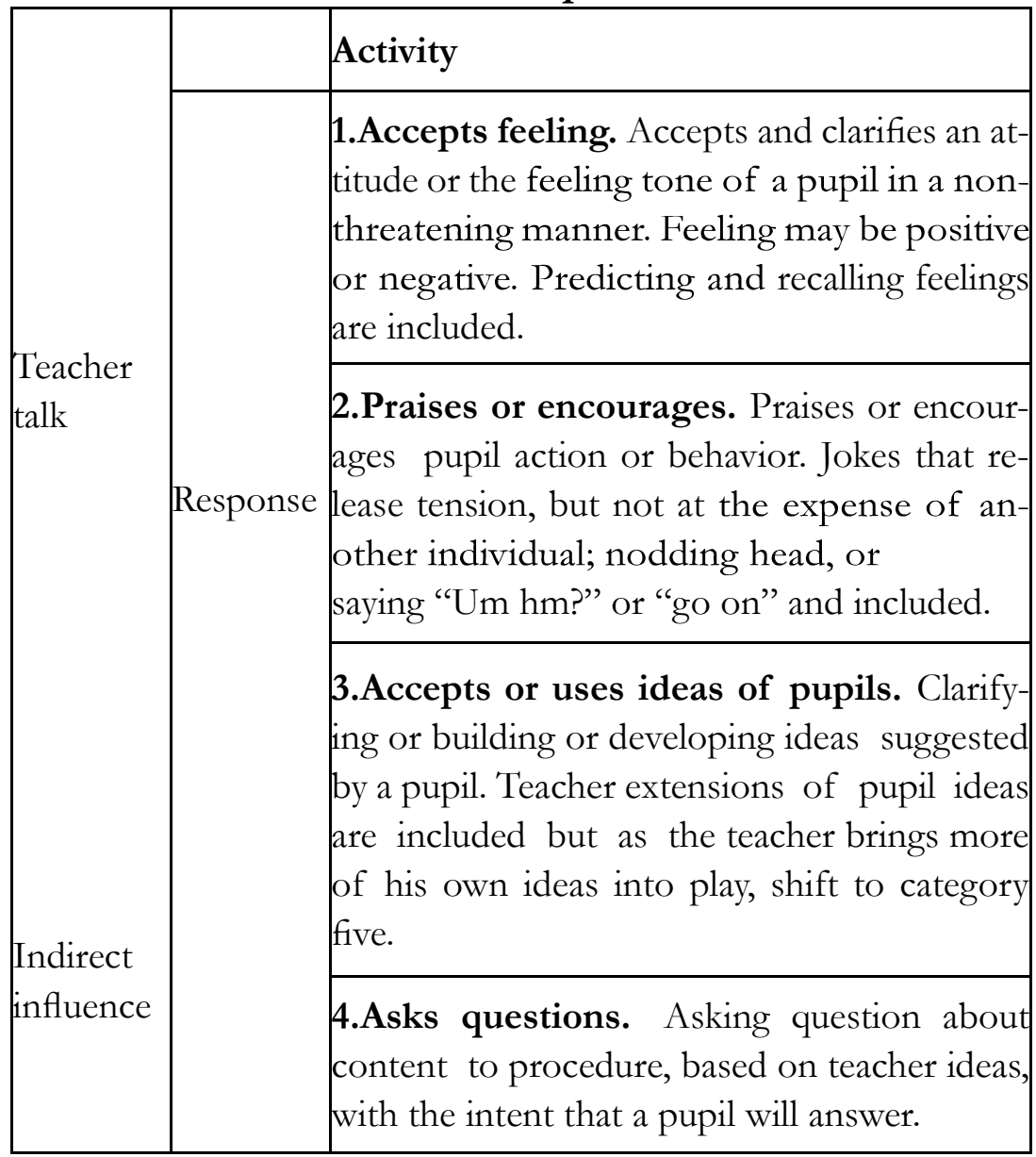




\begin{tabular}{|c|c|c|}
\hline \multirow{3}{*}{$\begin{array}{l}\text { Direct } \\
\text { influence }\end{array}$} & \multirow{3}{*}{ Initiation } & $\begin{array}{l}\text { 5.Lecturing. Giving facts or opinions about } \\
\text { content or procedures; expressing his own } \\
\text { ideas, giving his own explanation, or citing an } \\
\text { authority other than a pupil. }\end{array}$ \\
\hline & & $\begin{array}{l}\text { 6.Giving directions. Directions, commands } \\
\text { or orders to which a pupil is expected to com- } \\
\text { ply. }\end{array}$ \\
\hline & & $\begin{array}{l}\text { 7.Criticising or justifying authority. } \\
\text { Statements intended to change pupil behav- } \\
\text { ior from non-acceptable to acceptable pat- } \\
\text { tern; bawling someone out; stating why the } \\
\text { teacher is doing what he is during; extreme } \\
\text { self-reliance. }\end{array}$ \\
\hline \multirow[b]{2}{*}{ Pupil talk } & Response & $\begin{array}{l}\text { 8.Pupil-talk response. Talk by pupils in re- } \\
\text { sponse to teacher. Teacher initiates the contact } \\
\text { or solicits pupil statement or structures the } \\
\text { situation. Freedom to express own ideas is } \\
\text { limited. }\end{array}$ \\
\hline & Initiation & $\begin{array}{l}\text { 9.Pupil-talk Initiation. Talk by pupils, } \\
\text { which they initiate. Expressing own ideas; } \\
\text { initiating a new topic; freedom to develop } \\
\text { opinions and a line of thought, kike asking } \\
\text { thoughtful questions; going beyond the exist- } \\
\text { ing structure. }\end{array}$ \\
\hline Silence & & $\begin{array}{l}\text { 10.Silence or confusion. Pauses, short pe- } \\
\text { riods of confusion in which communica- } \\
\text { tion cannot be understood by the observer. }\end{array}$ \\
\hline
\end{tabular}

\section{METHODS}

\section{Research Design}

The research design is descriptive qualitative because the goal of the study is to get a clear description of interaction between 
teacher and students for the teaching-learning process in an English classroom, to know the kinds of interaction based on the characteristics of the teacher-students' interaction in the classroom and to identify Indonesian or English language used in the classroom interaction by knowing the percentage of English and Indonesian language used for teaching-learning process.. Since the interaction is a process which involved human behavior in its natural setting the researcher decided to make use of the qualitative approach to the study. As Nunan (1992:4) suggests, qualitative methods, concern with the understanding of human behaviour from the actor's own frame of reference, exploratory, descriptive and process-oriented.

\section{Subject of the Study}

The subject of this study was the eighth grade students of SMP Negeri 18 Purworejo in the academic year of 2012/2013 in the English class. The researcher did the research in the class VIII G, there are 40 students and their English teacher, Ms. TitikKusumawati, S.Pd.

\section{The Type of Data}

The data of the study were collected in the form of recorded classroom interaction and the observation field notes. The two types of database were examined in order to identify what kinds of activity were involved in the teacher-student interaction. The activities could be lecturing, questioning and answering, and also discussion. It found that the interaction contained the teacher talk and the students talk as well as teacher activity and students' activity. In other words, the data of the study were in the form of speech and actions and then the researcher arranged the transcription of the data.

\section{Techniques of Collecting Data}

Observation is the act of collecting data about the performance of a subject through the five senses; sight, smelling, hearing, touching and taste. (Arikunto, 2010:199). The observation was conducted twice in the classroom. Each observation lasted eighty minutes. The observer directly observed in the classroom, and took notes on the 
relevant events while the teaching-learning process was going on.

The data collection activity was conducted through several steps. First, the researcher fulfilled some formal administrative procedure including getting the school principal's permission to collect data, that is doing observation in the school classrooms. As soon as the permission was given, the researcher met the English teacher to make an appointment for doing the observation. The data in this research were in the form of words, phrases, sentences taken from the data resources (field notes \& transcript). The data resources were taken by using observation.

The data to be analyzed in this study were the data of the teacher-students interaction in the classroom. In this study, the researcher analyzed the observed data by using Flanders' Interaction Analysis Categories suggested by Alwright and Bailey (1991:10, 202-203).

\section{FINDINGS}

The first observation was made on April $12^{\text {th }}, 2013$ at 07.00 a.m. to 08.20 a.m. and the second was on April $13^{\text {th }}, 2013$ at 08.20 a.m. to 09.55 a.m. After recording and encoding the classroom events into ten categories, the researcher concerned with the construction of an interaction matrix table. It consists of ten rows and ten columns. The category number of the record is tabulated in the matrix table. Each number is entered in the form of sequence pairs that used twice; firstly as the first number and secondly as the second number.

\section{Plotting code}

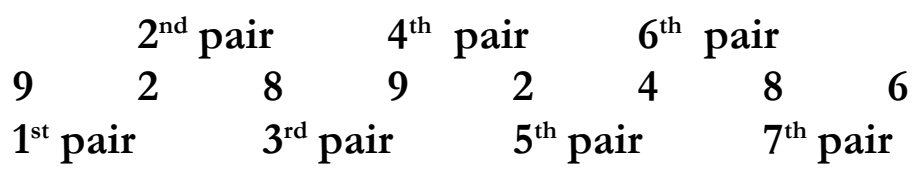

The ordered pairs were then tabulated in the appropriate cells of $10 \times 10$ matrixes with row and column headings 1 to 10 . The row indicates by the first number and the column indicates by the second number. The first pair is 92 ; the tally is placed in row nine 
and column two cell. The second pair is 28 ; the tally is placed in row two and column eight cell. The third pair is 89 ; the tally is placed in row eight and column nine cell. The fourth pair is 92 ; the tally is placed in row nine and column two cell, and so on. The results of the classroom observations are presented in following table.

Table 2. Matrix Classroom Interaction of VIII.G SMP N 18 Purworejo

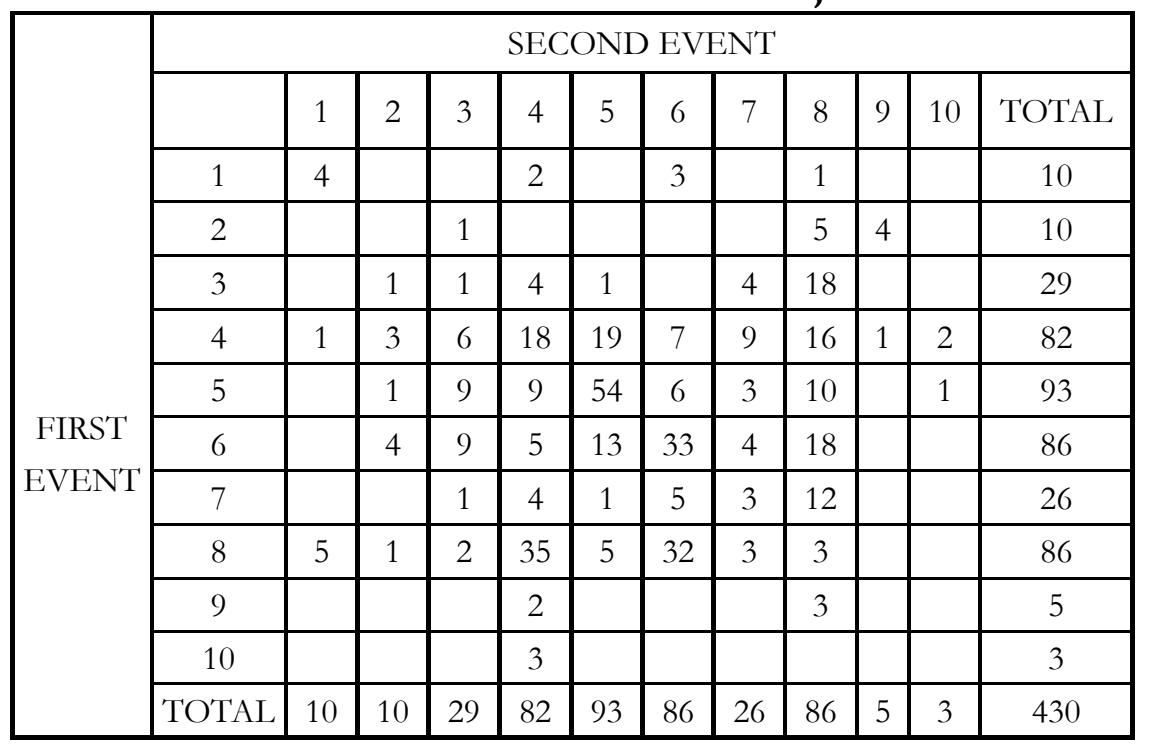

\section{Notes:}

1. Accepts feeling

2. Praises or encourages

3. Accepts or uses ideas of students

4. Asks questions

5. Lecturing

6. Giving directions

7. Criticizing or justifying authority

8. Student-talk response

9. Student-talk initiation

10. Silence 
An Analysis of Teacher and Student Talk ...

The following table shows the result of percentage based on the tabulationmatrix.

Table 3. Percentage all categories

\begin{tabular}{|c|l|c|c|}
\hline NNpp & \multicolumn{1}{|c|}{ P } & FrequenFcF & $\begin{array}{c}\text { Percentage } \\
(\%)\end{array}$ \\
\hline 1. & Accepts feeling & 10 & 2.33 \\
\hline 2. & Praises or encourages & 10 & 2.33 \\
\hline 3. & Accepts or uses ideas of students & 29 & 6.74 \\
\hline 4. & Asks questions & 82 & 19.07 \\
\hline 5. & Lecturing & 93 & 21.63 \\
\hline 6. & Giving directions & 86 & 20.00 \\
\hline 7. & Criticizing or justifying authority & 26 & 6.05 \\
\hline 8. & Students-talk response & 86 & 20.00 \\
\hline 9. & Students-talk initiation & 5 & 1.16 \\
\hline 10. & Silence & 3 & 0.69 \\
\hline & TOTAL & 430 & $100 \%$ \\
\hline
\end{tabular}

From the table 6 above, it can be seen that the percentage of teachertalk in the classroom interaction was $78.15 \%$.It was spent in the followingways:
a. Accepting feeling
$2.33 \%$
b. Praise or encouragement
$2.33 \%$
c. Accepting and use of students' ideas
$6.74 \%$
d. Asking questions
$19.07 \%$
e. Lecturing
$21.63 \%$
f. Giving directions
$20.00 \%$
g. Criticizing and justifying authority
$6.05 \%$

Percentage of the students' talk was $21.16 \%$ and was spent in thefollowing ways:
a. Students talk response $20.00 \%$
b. Students talk initiation $1.16 \%$ 
Silence or confusion constitutes $0.69 \%$ of the whole interaction behaviors.

According to Mohan Radha (2011) we can see whether the teacher is more indirect or direct on her teaching by comparing between indirect influence and direct influence. To calculate the ratio is by dividing the numberof the category 1-4 and the number of category 5-7 (based on the table 6). If the ratio is 1 or more than 1 , the teacher is classified to be indirect in her teaching. While the ratio is less than 1 , the teacher is said to be direct in her teaching. The result is $131: 205=0.64$; it means the teacher is more direct on her teaching. The activities of direct influence in teaching are lecturing and giving directions to the students for teaching learning process.

Based on the table 3 above, the researcher analyzed the characteristic of the interaction.

\section{a. Content Cross}

By adding the percentage category 4 and 5 , we know the Content Cross. The Content Cross shows how the teacher delivers questions and lectures.

\section{Table 4. Content Cross}

\begin{tabular}{|c|c|}
\hline Name & Percentage \\
\hline Category 4 : asks question & $19.07 \%$ \\
\hline Category 5 : lecturing & $21.63 \%$ \\
\hline Content cross & 40.70 \\
\hline
\end{tabular}

\section{b. Teacher Control}

By adding the percentage category 6 and 7, we know the total of the teacher control. The Teacher Control shows that teacher gives commands and reprimands to the students. 
An Analysis of Teacher and Student Talk ...

Table 5. Teacher Control

\begin{tabular}{|c|c|}
\hline Name & Percentage \\
\hline Category 6 : giving directions & $20.00 \%$ \\
\hline Category 7 : criticizing or justifying authority & $6.05 \%$ \\
\hline Teacher Control & $26.05 \%$ \\
\hline
\end{tabular}

\section{c. Teacher Support}

By adding the percentage category 1, 2 and 3, we know the total of teacher support. The Teacher support shows that teacher made reinforcement and encouragement to the students.

Table 6. Teacher Support

\begin{tabular}{|c|c|}
\hline \multicolumn{1}{|c|}{ Name } & Percentage \\
\hline Category 1 : accepts feeling & $2.33 \%$ \\
\hline Category 2 : praises or encourages & $2.33 \%$ \\
\hline Category 3: accepts or uses ideas of students & $6.74 \%$ \\
\hline Teacher Support & $11.40 \%$ \\
\hline
\end{tabular}

\section{d. Student Participation}

By adding the percentage of category 8 and 9, we know theStudent Participation. The Student participation shows that the students give response or ask question to the teacher.

\section{Table 7. Student Participation}

\begin{tabular}{|cc|c|}
\hline \multicolumn{2}{|c|}{ Category } & Percentage \\
\hline Category 8 & : students-talk response & $20.00 \%$ \\
\hline Category 9 & : students-talk initiation & $1.16 \%$ \\
\hline \multicolumn{2}{|c|}{ Student Participation } & $21.16 \%$ \\
\hline
\end{tabular}

The summary of the result of characteristic interaction above are presented in the table below. 


\section{Table 8 The summary result of interaction} characteristics

\begin{tabular}{|c|c|c|}
\hline No & Name & Percentage \\
\hline 1. & Content Cross & $40.70 \%$ \\
\hline 2. & Teacher Control & $26.05 \%$ \\
\hline 3. & Teacher Support & $11.40 \%$ \\
\hline 4. & Student Participation & $21.16 \%$ \\
\hline 5. & Silent & $0.69 \%$ \\
\hline & TOTAL & $100 \%$ \\
\hline
\end{tabular}

From the table 8 above, we can see that content cross dominates the teaching learning process; it means the teacher asks question and gives lessons to her students during the teaching learning process.

The information about the use of language in the classroom interaction was also gathered. The table below shows the language used in the classroom interaction.

Table 9. The language used for classroom interaction

\begin{tabular}{|c|c|c|c|}
\hline \multirow{2}{*}{ Language } & \multirow{2}{*}{ Speaker } & \multicolumn{2}{|c|}{ Observation } \\
\cline { 3 - 4 } & & Frequency & $\%$ \\
\hline \multirow{3}{*}{ English } & Teacher & 120 & $27 \%$ \\
\cline { 2 - 4 } & Students & 48 & $11 \%$ \\
\cline { 2 - 4 } & Total & 168 & $38 \%$ \\
\hline \multirow{3}{*}{ Indonesia } & Teacher & 226 & $52 \%$ \\
\cline { 2 - 4 } & Students & 44 & $10 \%$ \\
\cline { 2 - 4 } & Total & 270 & $62 \%$ \\
\hline \multirow{2}{*}{ Total } & Overall & 438 & $100 \%$ \\
\hline
\end{tabular}


From the table 9 above, Indonesian language used more than English because it took $62 \%$, while English was only 38\%. The teacher used Indonesian mostly when she lectured and translate the material in order to make students understand well.

In short, the language used as a medium of instruction was almost entirely in Indonesian, with some English inserted. English was also used for delivering materials at the same time Indonesian sentences were also used as translation for explaining the meanings.

\section{DISCUSSION}

From the overall result of observation displayed in the research finding, we can see that the most time-spend of teacher and student talk in the classroom interaction was the teacher talk which occupied $78.15 \%$ of time, whereas the student talk occupied $21.16 \%$. The rest $0.69 \%$ of the time was that of silence, confusion or unclassified talk. It can also be seen that from the whole time of teacher talk, it was mostly spent for asking questions, lecturing and giving directions, while most of students talk was for giving responses.

The result of the study showed that teacher talk was $78.15 \%$, students talk was $21.16 \%$, and silent was $0.69 \%$ of the time. Only a small part of the student talk shows initiation related to the learning materials. Instead, they talked a lot when they gave responses to the teacher's lecture or questions.

The teacher is more direct in her teaching. It can be seen from the ratio between direct and indirect influence, the result is less than 1. It means that the teacher gives lessons (lecturing) and gives directions to the students during teaching learning process. The teacher attempts to make her students being more active in the class by giving chance for students to ask when the teacher was lecturing. A conclusion can be drawn that teacher dominates the teaching learning process. The students rarely ask questions to the teacher but they always respond teacher's questions. 


\section{CONCLUSION}

Based on the data analysis and the result of the study above, the researcher concludes that:

1. The teacher talk is $78.15 \%$, the student talk is $21.16 \%$, and the silence is $0.69 \%$. It means that the teacher dominates the class. The teacher is more active while the students are less active. Thestudent talking time is used largely for responding to the teacher's questions or lecture.

2. The teacher used direct influence more in teaching her students than indirect influence. It is known by the ratio between direct and indirect influence is less than 1 . The activities of direct influence in teaching are lecturing and giving directions to the students for teaching learning process.

3. The language in classroom used by the teacher and $t \mathrm{~h} \mathrm{e}$ students in classroom interaction did not balance between Indonesian and English. Indonesian language is $62 \%$ while English is 38\%. It shows that theteacher used more Indonesian than English when she explains the material. The teacher speaks Indonesian more than English in order to make students better understand the materials. 


\section{REFERENCES}

Allwright, D. \& Kathleen M. Bailey.1991. Focus on the Language Classroom: An Introdution to Classroom Research for Language Teachers. New York: Cambridge University Press.

Arikunto, Suharsimi. 2010. ProsedurPenelitian: SuatuPendekatanPraktik. Jakarta RinekaCipta.

Cox, Carole. 1999. Teaching Language Arts a Student- and ResponseCenteredClassroom. New York: California State University

Ellis, Rod. 1994. The Study of Second Language Acquisition. Oxford: Oxford University Press.

Hornby, A S.1997. Oxford Advanced Learner's Dictionary. Oxford : Oxford University Press.

Icbay, Mehmet A. 2008. The Role of Classroom Interaction in the Construction of Classroom Order: A Conversation Analytic Study. Thesis Doctor Philosophy. Middle East Technical University

Mohan, Radha. 2011. Teacher Education. New Delhi: PHI Learning Pvt.Ltd

Nunan, David.1992. Research Methods in Language Learning. New York: Cambridge University Press.

Ramelan. 1992. Introduction to Linguistics Analysis. Semarang: IKIP Semarang Press.

Richards, J.C. and David Nunan.1990. Second Language Teacher Education. New York: Cambridge University Press. 